\title{
MINIREVIEW
}

\section{GTP-Binding Proteins and Their Regulatory Actions on Ion Channels}

\author{
Makoto SATO \\ Department of Physiology, School of Medicine, \\ Iwate Medical University, Morioka, 020 Japan
}

The science of 'signal transduction mechanisms' is the most dramatically progressing field in cell biology during the past several years. Guanine nucleotidebinding proteins (G-proteins) have been identified in almost all cells in every tissue, and their major roles are known to transduce various intracellular signals by interacting between receptor molecules and effector enzymes or ion channels. They regulate synaptic transmission, contractions of cardiac and smooth muscles, secretions of endocrine and exocrine cells, translation system of the messenger RNA, and mitotic cell cycles $[17,21,58,61]$.

This paper describes basic structures and functions of G-proteins and focuses on their modulatory or regulatory actions for ionic channels in the plasma membrane while attempting to put forward some possible unifying concept from the diverse information that has accumulated.

\section{BASIC STRUCTURES AND FUNCTIONS OF G-PROTEINS}

G-proteins are solubilized from membranes by detergent as monomers of about $100 \mathrm{kDa}$. Each monomer is composed of $\alpha-, \beta$-, and $\gamma$-subunits. The $\beta$ - and $\gamma-$ subunits are about $35 \mathrm{kDa}$ and $8 \mathrm{kDa}$, respectively, and not very different among various species of G-proteins $[19,39]$. They are so tightly associated to each other that they are inseparable unless they are denatured. The $\alpha$-subunits are relatively larger molecules of $35-55 \mathrm{kDa}$, and different among the species of G-proteins. All $\alpha$ subunits are readily dissociable from $\beta \gamma$-subunits when G-proteins are activated simply by raising the temperature in GTP-containing solution [11] or by stimulating the receptors to which they are coupled $[43,67]$. In the inactive form of G-proteins, GDP is bound to the catalytic site of GTPase localized in $\alpha$-subunit. The conformational change in the receptor molecule elicited by agonist binding influences the coupling G-protein to release the bound GDP, then intracellular GTP takes the place of the same binding site, as an 'exchange reaction,' and starts to be hydrolyzed to GDP. The kinetics of this hydrolysis is relatively slow. During the hydrolysis, $\alpha-$

Received for publication July 14, 1989 
subunit of the G-protein dissociates from $\beta \gamma$-subunits. This stage is called 'Gprotein activation.' This activation is 'switched off' when hydrolyzed GDP reoccupies the catalytic site, and $\alpha$-subunit reassociates with $\beta \gamma$-subunits to form stabler conformation of the G-protein. Non-hydrolyzable GTP-analogues such as GTP $-\gamma \mathrm{S}$ and $\operatorname{Gpp}(\mathrm{NH}) \mathrm{p}$, therefore, can 'switch on' the G-protein activation irreversibly without causing 'switch off.'

Bacterial toxins such as cholera toxin (CTX) and pertussis toxin (PTX) include a protomer subunit which has an adenosine-diphosphate (ADP) -ribose transferase. These toxins can ADP-ribosylate $\alpha$-subunits of particular G-proteins in the presence of nicotinamide adenine dinucleotide (NAD) and sometimes ADP-ribosylating factor (ARF). For example, CTX ADP-ribosylates $\alpha$-subunits $\left(\alpha_{\mathrm{s}}\right)$ of $\mathrm{G}_{\mathrm{s}}$ (G-protein which stimulates adenylate cyclase) at the arginine residue near the GTPase, and activates $\mathrm{G}_{\mathrm{s}}$ irreversibly [62]. On the other hand, PTX ADP-ribosylates $\alpha$-subunits $\left(\alpha_{i}\right.$ and $\left.\alpha_{o}\right)$ of $G_{i}$ (G-protein which inhibits adenylate cyclase), and $G_{o}$ (other Gprotein which does not interfere with adenylate cyclase [49]). Generally, $G_{i}$ is 10 times more abundant than $G_{s}$ in the plasma membranes of most cells [20], and $G_{0}$ is 5-10 times more abundant than $\mathrm{G}_{i}$ in the whole brain [18]. The ADP-ribosylation by PTX occurs at the cysteine residue of these $\alpha$-subunits, and uncouples these Gproteins from their receptors $[25,63,65]$. CTX reduces GTPase activity at the $\alpha$ subunit of $\mathrm{G}_{\mathrm{s}}$ [9], but PTX does not impair GTPase activity at the $\alpha$-subunit of $\mathrm{G}_{\mathrm{i}}$ or $G_{0}$ [29]. Because of these specific effects of each toxin, they are extremely useful in identifying G-proteins in membranes and in studying G-protein functions.

In the visual system, rhodopsin is a receptor molecule for the light. Photoactivated rhodopsin can activate a $G$-protein $\left(G_{t}\right)$ called 'transducin.' $G_{t}$ is sensitive to both CTX and PTX $[1,65]$. The activated $\alpha_{t}$ can stimulate cyclic GMPphosphodiesterase to reduce intracellular cGMP and hyperpolarize the photoreceptor cells [60]. The $\beta \gamma$-subunits are generally hydrophobic and localized within a lipid layer of the membrane to anchor the hydrophilic $\alpha$-subunit, and important for maintaining the contact with each receptor molecule. Regulatory roles of $\alpha$ - and $\beta \gamma$ subunits for the ion channels are described below.

\section{G-PROTEIN-REGULATED OPENING OF $\mathrm{K}^{+}$-CHANNELS}

\section{(A) $\alpha$ - and B $\gamma$-subunits of $G_{\mathrm{i}}$ or $G_{\mathrm{o}}$}

Applying a single-channel recording technique to the chicken embryonic atrial muscle cells, Logothetis et al. [38] and NEER and Clapham [43] demonstrated that $10^{-9} \mathrm{M}$ order of $\beta \gamma$-subunits purified from bovine brain $\mathrm{G}$-proteins $\left(\mathrm{G}_{\mathrm{i}}\right.$ or $\left.\mathrm{G}_{\mathrm{o}}\right)$ could open $\mathrm{K}^{+}$-channels coupled to the muscarinic receptor of $\mathrm{M}_{2}$-type. On the other hand, YATANI et al. [72] and other researchers in Brown and Birnbaumer's group [70] showed that $10^{-12} \mathrm{M}$ order of $\alpha$-subunit purified from human erythrocyte Gproteins $\left(G_{i}\right)$ could open $K^{+}$-channels coupled to the muscarinic receptor of $\mathbf{M}_{2}$ type in the guinea pig atrial cell. There were heated debates between these two groups with respect to $\alpha$ - or $\beta \gamma$-subunits. 
Soon thereafter, however, LoGotheTIS et al. [37] concurred that both $\alpha$ - and $\beta \gamma$ subunits of $G_{i}$ but not $G_{i}$ isolated from bovine brain could open $K^{+}$-channels coupled to $\mathbf{M}_{2}$-receptors in the chicken embryonic atrial muscles, although they later considered that the action of $\beta \gamma$-subunits was different from that of $\alpha$-subunit, as described below.

\section{(B) Generality of $G_{\mathrm{i}}$ or $G_{\mathrm{o}}$ involvement}

Apart from the problem of $\alpha$ - or $\beta \gamma$-subunits, the involvement of PTX-sensitive $\mathrm{G}$-protein in $\mathrm{K}^{+}$-channel opening was found not to be specific to the channel coupled to the muscarinic receptor $\left(\mathrm{M}_{2}\right)$ in the mammalian heart. This was demonstrated by SASAKI and SATO $[54,55]$ in the ganglion cells of Aplysia. They proved that $\mathrm{K}^{+}$-channel openings elicited by stimulations of acetylcholine $(\mathrm{ACh})$ $\left(\mathrm{M}_{2}\right)$, dopamine $\left(\mathrm{D}_{2}\right)$, histamine $\left(\mathrm{H}_{2}\right)$, and phenylalanine-methionine-argininephenylalanine-amide (FMRFamide) $\left(\mathrm{F}_{\mathrm{k}}\right)$ receptors are all regulated by PTXsensitive G-proteins. Similar observations were made in Aplysia by other investigators $[6,66]$. In mammals, $\mathrm{K}^{+}$-channel openings were elicited by stimulations of serotonin (5HT-1A)- and GABA (B)-receptors in the hippocampal pyramidal cells of the rat [3], and by stimulations of adenosine receptors in atrial myocytes [33], and somatostatin receptors in pituitary tumor cells [69] or locus coeruleus neurons of the rat [26]; $\mathrm{K}^{+}$-channel openings were elicited by stimulations of noradrenaline $\left(\alpha_{2}\right)$ and opioid ( $\mu$ and $\delta$ ) receptors in the locus coeruleus neurons [2] and neuroblastoma-glioma hybrid cells [52]. All were found to be regulated by PTXsensitive G-proteins.

Historically, $G_{i}$, which inhibits adenylate cyclase, was the first G-protein found to be sensitive to PTX. Later, also $\mathrm{G}_{\mathrm{o}}$ and some $\mathrm{G}$-proteins which are considered to stimulate phospholipase $\mathrm{C}$ or $\mathrm{A}_{2}$ were found to be sensitive to PTX $[8,44]$. Activations of these G-proteins should trigger a variety of biochemical changes inside the cell, such as a decrease in cAMP, increase or decrease in $\mathrm{Ca}^{2+}$, inositol trisphosphate $\left(\mathrm{IP}_{3}\right)$, diacylglycerol $(\mathrm{DAG})$, arachidonic acid $(\mathrm{AA})$, and their metabolites. However, it should be remembered that the $\mathrm{K}^{+}$-channel openings triggered by activation of $\mathrm{G}_{\mathrm{i}}$ or $\mathrm{G}_{\mathrm{o}}$ could occur independently from intracellular biochemical changes mentioned above, although the latter changes could have some modulatory effects on the former.

\section{(C) Definitions of $G_{\mathrm{k}}$ and $G_{\mathrm{p}}$ and their functions}

Some G-proteins which are responsible for stimulation of phospholipase $\mathrm{C}$ and resultant phosphatidylinositol (PI) turnover, are also sensitive to PTX. For example, the stimulation of bradykinin receptors in NG108-15 cells activates this kind of G-protein and induces the opening of $\mathrm{Ca}^{2+}$-dependent $\mathrm{K}^{+}$-channels, but this is subsequently blocked by activation of protein kinase $\mathrm{C}$ [7]. However it should be noted that the opening of $\mathrm{Ca}^{2+}$-dependent $\mathrm{K}^{+}$-channels is not the direct result of $\mathrm{G}$-protein activation. Instead, it is simply due to an increase in intracellular $\mathrm{Ca}^{2+}$ released from the endoplasmic reticulum after activation of phospholipase $\mathrm{C}$. 
Accordingly, this G-protein should be different from other G-proteins described above.

It should also be remembered that the openings of $\mathrm{K}^{+}$-channels coupled to many receptors are all sensitive to PTX, but PTX-sensitive G-proteins are not always directly capable of opening the $\mathrm{K}^{+}$-channels. Therefore, it is reasonable to have the name ' $\mathrm{G}_{\mathbf{k}}$ ' for the G-protein that is sensitive to PTX and directly capable of opening $\mathrm{K}^{+}$-channels (not $\mathrm{Ca}^{2+}$-dependent $\mathrm{K}^{+}$-channels), as suggested by Brown and Birnbaumer's group [70,72], although it creates a little confusion with the term $\mathrm{G}_{\mathrm{k}}$ which is used to mean a potassium conductance in neurophysiology. The $\alpha$ subunit synthesized with cDNA for $G_{k}$ was found to be identical to $\alpha_{i}-3$, although $\alpha_{i}-1$ and $\alpha_{i}-2$ were both capable of opening $\mathrm{K}^{+}$-channels [72].

Stimulations of the adrenergic receptor of $\alpha_{1}$-type, muscarinic receptor of $\mathrm{M}_{1}$ type, thyrotropin-releasing hormone (TRH) receptor of $\mathrm{GH}_{3}$ cells, and thrombin receptor of fibroblast cells are known to activate phospholipase $\mathrm{C}$. They are sensitive to neither CTX nor PTX, and never open $\mathrm{K}^{+}$-channels $\left(\mathrm{Ca}^{2+}\right.$ independent) during their responses [36]. Generally the G-proteins which activate phospholipase $\mathrm{C}$ but are not sensitive to either CTX or PTX seem to be incapable of directly opening the $\mathrm{K}^{+}$-channel $\left(\mathrm{Ca}^{2+}\right.$-independent), although the reason for this is not well understood at this moment; this group of G-proteins are considered to be different from $G_{k}$, and called ' $G_{p}$ '. Accordingly, the name $G_{p}$ should be used distinctly from other $\mathrm{G}$-proteins which stimulate phospholipase $C$ but are sensitive to either CTX or PTX (See IV. below). $G_{k}$ seems to be different from other $G_{i}$ or $G_{o}$ because $G_{k}$ activation scarcely causes the stimulation of PI turnover in the cells so far examined. Is the $G_{k}$ never capable of metabolizing any phospholipid?

Recently, there is accumulating evidence suggesting that $G_{k}$ might stimulate phospholipase $\mathrm{A}_{2}$. Agonist-induced stimulations of the adrenergic receptor of $\alpha_{2}$ type, opiate receptor of $\delta$-type, and muscarinic receptor of $\mathrm{M}_{2}$-type are known to activate $\mathrm{G}_{\mathrm{k}}$, as mentioned above. Interestingly, these stimulations also cause a slight increase $(0.3)$ in intracellular $\mathrm{pH}$ in all cells examined. This increase in $\mathrm{pH}$ has been considered to be the result of $\mathrm{G}_{\mathrm{k}}$-induced acceleration of $\mathrm{Na}^{+} / \mathrm{H}^{+}$exchange. These changes would cause an increase in intracellular $\mathrm{Ca}^{2+}$ and alkalization, both being favorable for activation of phospholipase $\mathrm{A}_{2}$ [4, 35]. For example, stimulation of FMRFamide receptors of Aplysia sensory neuron activates $\mathrm{G}_{\mathrm{k}}$ to produce $\mathrm{K}^{+}$dependent hyperpolarization. During this response, many lipoxygenase products such as labeled 12-HPETE and 5-HETE were secreted from the cell and detected by high-performance liquid chromatography (HPLC) [5, 47]. It was even considered that these lipoxygenase metabolites were primarily responsible for activating the $\mathrm{K}^{+}$-channels because the lipoxygenase inhibitor nordihydroguaiaretic acid (NDGA) effectively blocked the FMRFamide-induced hyperpolarization. As mentioned earlier, Neer and Clapham's group of investigators initially described that $\beta \gamma$-subunits of $\mathrm{G}_{\mathrm{k}}$ are responsible for opening the $\mathrm{K}^{+}$-channels coupled to the muscarinic receptors of atrial muscles [38]. More recently, they described that $\beta \gamma$ subunits of $G_{k}$ activate phospholipase $A_{2}$ to release arachidonic acid (AA) from the 
lipid membrane [30]. AA is further metabolized by lipoxygenase to produce 5HPETE, 12-HETE, and leukotrienes $\left(\mathrm{B}_{4}, \mathrm{C}_{4}\right)$ [32]. They also think that these lipoxygenase products are primarily responsible for opening the $\mathrm{K}^{+}$-channels of atrial myocytes [30]. The $\beta \gamma$-subunits of $\mathrm{G}_{\mathrm{t}}$ are also known to activate phospholipase $A_{2}$ in the rod outer segments [27], though their ability to open $\mathrm{K}^{+}$-channels remains unknown.

(D) Physiological and pharmacological properties of the $G_{\mathrm{k}}$-dependent $K^{+}$channels

$\mathrm{G}_{\mathbf{k}}$-dependent $\mathrm{K}^{+}$-channels recorded from atrial muscles were first considered to have an inward rectifying characteristic. However, more precise analysis with a single-channel recording proved that the kinetics of $\mathrm{K}^{+}$-channel opening by $\mathrm{ACh}$ was considerably different from that of inward rectifying $\mathrm{K}^{+}$-channel [53], and does not show much inward rectification within the voltage range from -100 to $-25 \mathrm{mV}$. On the other hand, KURACHI et al. [32] described that the $\mathrm{K}^{+}$-channel opened by AA [38] exhibited a strong inward rectification in the same cardiac myocyte. This is rather an interesting discrepancy, because $\mathrm{K}^{+}$-channels coupled to ACh, histamine, FMRFamide, and dopamine in Aplysia neurons demonstrated practically no signs of inward rectification (our unpublished observation). Definitely, they are not the $\mathrm{Ca}^{2+}$-activated $\mathrm{K}^{+}$-channels. They are not readily blocked by tetraethylammonium (TEA) or apamin, but depressed by aminopyridines or simply by lowering the temperature [22]. They are similar to S- or Mchannels because intracellular injections of cAMP or cGMP significantly depress the opening of these $\mathrm{K}^{+}$-channels. Phorbol esters also depress these $\mathrm{K}^{+}$-channel activities [10]. These findings suggest that protein kinases $A, G$, and $C$ can phosphorylate either these $\mathrm{K}^{+}$-channels or $\mathrm{G}_{\mathrm{k}}$ to deactivate them. In fact, $\mathrm{G}_{\mathrm{k}}$ has been proved to be a good substrate for protein kinase $\mathrm{C}$ [28].

\section{G-PROTEIN-REGULATED OPENING OF $\mathrm{Na}^{+}-$AND $\mathrm{Ca}^{2+}$-CHANNELS}

\section{(A) Voltage-dependent nature of these ion channels}

A number of receptors for neurotransmitters and hormones have been known to stimulate the adenylate cyclase and cause excitation or secretion in many neurons and secretory cells. These excitatory and secretory effects are generally associated with the occurrence of so-called 'slow inward current' across these receptor membranes. The ionic mechanisms underlying this 'slow inward current' have been ascribed to the opening of voltage-dependent $\mathrm{Na}^{+}$-channels or $\mathrm{Ca}^{2+}$-channels, and/or the concomitant closing of the specific $\mathrm{K}^{+}$-channels (S-channels). The exact identification of ion channels involved in this slow inward current is very difficult because these $\mathrm{Na}^{+}$- and $\mathrm{Ca}^{+}$-channels are voltage dependent and often exhibit a characteristic negative conductance when activated by receptor stimulation [40]. When these responses are examined under the whole cell voltage-clamp at potentials near the resting level, the apparent slope conductance of the membrane often 
decreases during the slow inward current [40], as if $\mathrm{K}^{+}$-channels were closed. Even with the patch-clamp technique, the openings of these $\mathrm{Na}^{+}$- and $\mathrm{Ca}^{2+}$-channels and concomitant closing of $\mathrm{K}^{+}$-channels, if it occurs, would be difficult to demonstrate them all at the same time.

\section{(B) Roles of $C A M P$ and $C G M P$}

Intracellular injection of cAMP or cGMP into the cells of olfactory cilia produces slow inward current and this response is considered as the direct action of cyclic nucleotide to open voltage-dependent $\mathrm{Na}^{+}$-channels, rather than mediated by cyclic nucleotide-dependent protein kinase A or G [51]. The cyclic GMP-induced depolarizing responses of the cone and rod in retina are also considered as the direct action of cGMP to open voltage-dependent $\mathrm{Na}^{+}$-channels and not due to the activation of protein kinase $G$ [51]. Not only these primary sensory cells, but many neurons in the Aplysia ganglion respond to both cyclic AMP and GMP with a prompt activation of voltage-dependent $\mathrm{Na}^{+}$-channels but not $\mathrm{Ca}^{2+}$-channels even after the treatment with inhibitors for protein kinases $A$ and $G$ (our unpublished observation). Further studies are needed to explain these direct effects of cyclic nucleotides, which are independent of protein kinase activations.

\section{(C) Roles of protein kinases $A$ and $G$}

In cardiac myocytes, intracellular injection of the catalytic subunit of protein kinase $\mathrm{A}$ increases an open probability of the voltage-dependent $\mathrm{Ca}^{2+}$-channels [45]. In fact, the dihydropyridine-sensitive $\mathrm{Ca}^{2+}$-channel complex purified from skeletal muscles has been proved to be actually phosphorylated by protein kinase $\mathrm{A}$ [16]. In snail neurons, intracellular injection of the protein kinase $G$ increases the activity of voltage-dependent $\mathrm{Ca}^{2+}$-channels as well as the 5HT-induced $\mathrm{Ca}^{2+}$ current [46]. Accordingly, it can be said that both cyclic nucleotides themselves and their related protein kinases (A and $\mathrm{G}$ ) act synergistically to open voltagedependent $\mathrm{Na}^{+}$- and $\mathrm{Ca}^{2+}$-channels when receptors are stimulated. In addition, it should be remembered that the $\mathrm{K}^{+}$-channel activities regulated by $\mathrm{G}_{\mathrm{k}}$ could be depressed at the same time by activated protein kinase $A$ or $G$ as mentioned above.

\section{(D) Direct action of $\alpha_{\mathrm{s}}$ subunit}

Further surprising experiments were performed by investigators in Brown and Birnbaumer's group after they completed their work on $G_{k}$. They demonstrated that the $\alpha$-subunit of $G_{s}$ purified from the human erythrocyte membranes can activate the dihydropyridine-sensitive $\mathrm{Ca}^{2+}$-channels of the cardiac myocyte as well as the $\mathrm{Ca}^{2+}$-channels of skeletal muscle $\mathrm{T}$-tubules incorporated into the planar lipid bilayers [41, 71]. The most important fact they discovered is that the purified $\alpha_{\mathrm{s}}$ of nM order can activate these $\mathrm{Ca}^{2+}$-channels rather directly, being independent of actions of cyclic AMP and protein kinase A. The experiments of $G_{s}$ synthesis with cDNA in Escherichia coli revealed at least four different types of $\alpha$-subunits: S-1, S2, L-1, and L-2 (S and L denote the shorter and longer peptide chains, respectively) 
[41]. They proved that not only S-1 type but also S-2 and L-1 types of $\alpha$-subunits could activate $\mathrm{Ca}^{2+}$-channels, although they were less potent than natural $\alpha_{\mathrm{s}}$. They concluded that the activation of $\mathrm{G}_{\mathrm{s}}$ by receptor stimulation induces stimulatory effects on both the adenylate cyclase and voltage-dependent $\mathrm{Ca}^{2+}$-channels at the same time, each effector being activated independently but synergistically for the ultimate activation of $\mathrm{Ca}^{2+}$-channels.

\section{ACTIVATIONS OF PHOSPHOLIPASE C AND THEIR EFFECTS ON ION CHANNELS}

There are at least three different subtypes in the family of G-proteins which stimulate phospholipase C. First of all, $G_{p}$ is a substrate for neither PTX nor CTX. The receptors which are likely to be coupling with $G_{p}$ are described above. PTXsensitive $\mathrm{G}$-proteins which stimulate phospholipase $\mathrm{C}$ are coupled with the formylpeptide receptor in the myeloid differentiated HL-60 cells, $\alpha_{1}$-adrenergic receptor in adipocytes, thrombin receptor in hamster fibroblast cells, and bradykinin receptor in dorsal ganglion hybrid cells and neuroblastoma $\times$ glioma 108 cells. CTX-sensitive G-proteins which stimulate phospholipase $C$ are coupled with the antigen receptor in T-cell line Jurkat, secretin receptor in rat pancreatic acinar cells, and vasopressin receptor in WRK-1 mammary tumor cells [36]. The effect of CTX on the adenylate cyclase system is a persistent activation of the cyclase, whereas CTX does not activate phospholipase $\mathrm{C}$ but inhibits receptor-stimulated PI turnover.

Phospholipase $\mathrm{C}$ is the enzyme which hydrolyzes phosphatidylinositol biphosphate to produce $\mathrm{IP}_{3}$ and $\mathrm{DAG}$. $\mathrm{IP}_{3}$ can be further phosphorylated by intrinsic enzymes to form $\mathrm{IP}_{4}, \mathrm{IP}_{5}$, and $\mathrm{IP}_{6} . \mathrm{IP}_{3}$ is known to act on the endoplasmic reticulum and release $\mathrm{Ca}^{2+}$ from the storage site. The increase in intracellular $\mathrm{Ca}^{2+}$ concentration should cause the openings of $\mathrm{Ca}^{2+}$-activated $\mathrm{K}^{+}$-channels or $\mathrm{Ca}^{2+}$ activated $\mathrm{Cl}^{-}$-channels. These were actually proved in the cultured neuroblastoma $\times$ glioma hybrid cells when phospholipase $\mathrm{C}$ was activated by bradykinin receptor stimulation [7], and in Xenopus oocyte when phospholipase C was activated by $5 \mathrm{HT}$ and $\mathrm{ACh}$ [12]. DAG is known to activate protein kinase $\mathrm{C}$, which has been reported to block the activities of $\mathrm{Ca}^{2+}$-dependent $\mathrm{K}^{+}$-channels as well as $\mathrm{G}_{\mathrm{k}}$-operated $\mathrm{K}^{+}$-channels [14]. In fact, protein kinase $\mathrm{C}$ can phosphorylate PTX-sensitive G-proteins and deactivate them directly, thus blocking all $\mathrm{G}_{\mathrm{i}^{-}}, \mathrm{G}_{\mathrm{o}^{-}}$, and $\mathrm{G}_{\mathrm{k}}$-dependent reactions [28]. These effects of protein kinase $\mathrm{C}$ are always seen in all responses to stimulations of a variety of receptors which are considered to stimulate PI turnover, regardless of whether their G-proteins are sensitive to PTX or not. Peculiarly, however, the opening of $\mathrm{Ca}^{2+}$-activated $\mathrm{K}^{+}$-channels is seen only when PTX-sensitive G-proteins $\left(G_{i}\right.$ or $\left.G_{o}\right)$ are activated as in the cases of neuroblastoma $\times$ glioma hybrid cells and Xenopus oocytes, but never observed in the responses elicited by activation of $G_{p}$. Whether this is due to the difference of $G$ proteins or to the modulatory effects of other effector enzymes remains to be solved. 


\section{G-PROTEIN-REGULATED CLOSING OF $\mathrm{Ca}^{2+}$-CHANNELS}

\section{(A) Activations of PTX-sensitive G-proteins}

The activities of voltage-dependent $\mathrm{Ca}^{2+}$-channels are generally depressed whenever $G_{k}$ is activated by various receptor stimulations or by GTP- $\gamma$ S applied intracellularly. This was confirmed by opiate receptor of neuroblastoma glioma cells [23], $\alpha_{2}$-receptor [50], dopamine-receptor [64], GABA-B-type receptor of the dorsal root ganglion cell [13], and somatostatin receptor of pituitary cell line [34]. These depressing effects were all inhibited by PTX and GDP- $\beta$ S. The $\mathrm{Ca}^{2+}$-channels that were depressed by these receptor stimulations were T-type and $\mathrm{N}$-type channels while the L-type channels were not depressed significantly. It is of interest that the $\alpha$-subunits of $G_{0}$ and $G_{i}$ also have the same depressing effects on these $\mathrm{Ca}^{2+}$. channels, though the potency of $G_{o}$ is 10 times greater than that of $G_{i}$ [23]. These effects of $G_{k}$ and $G_{o}$ are considered to be the direct effects on the $\mathrm{Ca}^{2+}$-channels, and not due to the changes in activities of the adenylate cyclase system or of the protein kinase system.

HoRne et al. [24] extracted a crude $\mathrm{Ca}^{2+}$-channel complex from the triads of skeletal muscle of the rabbit, and isolated the $\mathrm{Ca}^{2+}$-channel activity component from its regulatory component. They proved that the $\mathrm{G}_{\mathrm{o}}$-dependent block occurred in the membrane reconstituted with the $\mathrm{Ca}^{2+}$-channel activity component isolated from its regulatory component. SCOTT and DoLPHIN [56] demonstrated in the dorsal root ganglion cells that intracellular injection of GTP- $\gamma \mathrm{S}$ depressed $\mathrm{Ca}^{2+}$-channel activities of the T- and N-types but not the L-type. Surprisingly, $\mathrm{Ca}^{2+}$-antagonists such as D600, nifedipine, and diltiazem markedly augmented $\mathrm{Ca}^{2+}$-current in the presence of GTP- $\gamma \mathrm{S}$ [56]. They interpreted this as the result of $\mathrm{Ca}^{2+}$-antagonists binding to the agonist binding sites during the activation of $G_{0}$ by GTP- $\gamma$ S.

Quite recently, I had a chance to meet with members of the USSR Academy of Sciences in Moscow. According to Prof. Fesenko, the director of the Institute of Biological Physics, Pushchino, 1-3 $\mu \mathrm{M} \alpha$-subunit of transducin $\left(\mathrm{G}_{\mathfrak{t}}\right)$ may directly block the cGMP-mediated opening of cationic $\left(\mathrm{Na}^{+}-\right.$and $\mathrm{Ca}^{2+}$ ) channels in the outer segment membrane of the rod [31]. This effect was confirmed with the excised membrane patch in the presence of $\mathrm{Br}-\mathrm{cGMP}$ and GTP- $\gamma \mathrm{S}$.

\section{(B) Involvement of protein kinase C?}

Direct suppressing effects of PTX-sensitive G-proteins on the opening of cationic channels were described above. However, there is a certain evidence that the activation of protein kinase $\mathrm{C}$, as secondary to the activations of these Gproteins, is responsible for the suppressing effects on the cationic channels.

Using the dorsal root ganglion cells dissected from 11-day chicken embryos, RANE and DUNLAP [48] demonstrated that DAG analogue 1,2-oleoylacetylglycerol (OAG) and phorbol ester 12-deoxyphorbol 13-isobutyrate (DPB) effectively depressed the voltage-gated $\mathrm{Ca}^{2+}$-current. Incubation of dorsal root ganglion cells with OAG prevented further reduction in $\mathrm{Ca}^{2+}$-current by norepinephrine, which is 
known to inhibit the voltage-dependent $\mathrm{Ca}^{2+}$-channel in these cells. From these results they suggested that the transmitter-induced inhibitions of $\mathrm{Ca}^{2+}$-current observed in dorsal root ganglion cells might be due to the activation of protein kinase $\mathrm{C}$.

The neuropeptide Y (NPY) is found in high concentrations in the dorsal horn of the spinal cord, and known to be the most potent inhibitor of the voltage-gated $\mathrm{Ca}^{2+}$-current in the dorsal root ganglion cells [15]. NPY stimulates the synthesis of DAG by dorsal ganglion cells and activates protein kinase $\mathrm{C}$. This peptide can depress not only the $\mathrm{N}$ - or $\mathrm{T}$-type $\mathrm{Ca}^{2+}$-current but also the $\mathrm{L}$-type $\mathrm{Ca}^{2+}$-current. However, it depressed mainly $\mathrm{N}$ - or $\mathrm{T}$-type $\mathrm{Ca}^{2+}$-current when examined after protein kinase $\mathrm{C}$ was deactivated by down regulation [15].

\section{NEUROPHYSIOLOGICAL RELEVANCE}

Apart from the involvement of protein kinase $C$, the fact that activation of $G_{0}$ inhibits the activity of $\mathrm{N}$-type $\mathrm{Ca}^{2+}$-channel is very important for the new concept of presynaptic inhibition, because $\mathrm{N}$-type $\mathrm{Ca}^{2+}$-channels are rich in presynaptic terminals and responsible for the control of transmitter release [42]. Presynaptic inhibition can occur by blocking $\mathrm{Ca}^{2+}$-influx through $\mathrm{N}$-type $\mathrm{Ca}^{2+}$-channels when receptors on the terminal membranes are stimulated by any neurotransmitters or hormones to activate $G_{0}$. It is no longer important whether presynaptic terminals are depolarized or hyperpolarized by these receptor stimulations.

The most abundant $G$-protein in the brain is $G_{0}$, comprising $1 \%$ of total membrane proteins [59]. $G_{0}$ is particularly rich in the hippocampus and frontal cortex, though it distributes widely in other areas of the brain. It is of interest that the $G_{0}$ distribution is parallel with the distribution of protein kinase $C$ in the brain [68]. This suggests the important roles of PI responses in the brain functions, causing mobilizations of $\mathrm{Ca}^{2+}$ inside the neuron, and phosphorylations of ion channels or their regulatory proteins.

A single neuron in the brain receives thousands of synaptic inputs on the cell body and dendrites. It acts as an integrating unit of all synaptic inputs impinging on it. It also receives hormonal or neurohumoral control which would alter the entire mode of integration. For example, if norepinephrine is liberated from a neighboring varicosity by stimulation of locus coeruleus neuron, it may react with extrajunctional $\alpha_{1}$-receptors which are coupled to $G_{0}$ and activate protein kinase $C$ in a certain neuron. Then, all the inhibitory input activities which would stimulate $G_{k}$ to produce hyperpolarization in the neuron could be suppressed because protein kinase $C$ would deactivate $\mathrm{G}_{\mathrm{k}}$ and $\mathrm{K}^{+}$-channel activities. In contrast, the excitatory input activities which would stimulate $G_{s}$ to produce depolarization in the same neuron could be augmented if protein kinase $C$ is mildly activated just to phosphorylate and deactivate $G_{i}$ [57]. However, they could be rather depressed if protein kinase $\mathrm{C}$ is activated intensely to phosphorylate the receptor protein itself [58]. Other synaptic inputs which would stimulate phospholipase $A_{2}$ to cause 
arachidonic cascade reactions could also be suppressed because protein kinase $\mathrm{C}$ would deactivate $G_{k}, G_{o}$, and $G_{i}$.

A single receptor molecule may be coupled to multiple G-proteins, and a single G-protein may be coupled to multiple effector enzymes and ion channels. These complexed biochemical changes are all integrated to determine the ultimate excitability and firing pattern of the single neuron, which is conveyed to the succeeding neuron as processed information. The basic studies on the regulatory roles of G-proteins for various ion channels are important not only for understanding the signal transduction mechanisms in a single cell level but also for providing the molecular basis for information processing in the brain, such as long-term potentiation or inhibition, habituation, and heterosynaptic facilitation, etc.

Key words: G-proteins, ion channels, receptors, PTX, CTX.

\section{REFERENCES}

1. Abood, M. E., Hurley, J. B., Pappone, M.-C., Bourne, H. R., and Stryer, L. (1982) Functional homology between signal-coupling proteins. Cholera toxin inactivates the GTPase activity of transducin. J. Biol. Chem., 257: 10540-10543.

2. Aghajanian, G. K. and WANG, Y.-Y. (1987) Common $\alpha_{2}$ - and opiate effector mechanisms in the locus coeruleus: Intracellular studies in brain slices. Neuropharmacology, 26: 793-799.

3. Andrade, R., Malenka, R. C., and Nicoll, R. A. (1986) A G-protein couples serotonin and $\mathrm{GABA}_{\mathrm{B}}$ receptors to the same channels in hippocampus. Science, 234: $1261-1265$.

4. Banga, H. S., Simons, E. R., Brass, L. F., and Rittenhouse, S. E. (1986) Activation of phosphotipases $\mathrm{A}$ and $\mathrm{C}$ in human platelets exposed to epinephrine: Role of glycoproteins IIb/IIIa and dual role of epinephrine. Proc. Natl. Acad. Sci. U.S.A., 83: 9197-9201.

5. Belardetti, F. and Siegelbaum, S. A. (1988) Up-and down-modulation of single $\mathrm{K}^{+}$ channel function by distinct second messengers. Trends Neurosci., 11: 232-238.

6. BřEZINA, V. (1988) Guanosine 5'-triphosphate analogue activates potassium current modulated by neurotransmitters in Aplysia neurones. J. Physiol. (Lond.), 407: 15-40.

7. Brown, D. A. and Higashida, H. (1988) Inositol 1,4,5-trisphosphate and diacylglycerol mimic bradykinin effects on mouse neuroblastoma $\times$ rat glioma hybrid cells. $J$. Physiol. (Lond.), 397: 185-207.

8. Burch, R. M., Luini, A., and Axelrod, J. (1986) Phospholipase $\mathrm{A}_{2}$ and phospholipase $\mathrm{C}$ are activated by distinct GTP-binding proteins in response to $\alpha_{1}$-adrenergic stimulation in FRTL5 thyroid cells. Proc. Natl. Acad. Sci. U.S.A., 83: 7201-7205.

9. CASSel, D. and Selinger, Z. (1977) Mechanism of adenylate cyclase activation by cholera toxin: Inhibition of GTP hydrolysis at the regulatory site. Proc. Natl. Acad. Sci. U.S.A., 74: 3307-3311.

10. Christie, M. J. and North, R. A. (1988) Control of ion conductances by muscarinic receptors. Trends Pharmacol. Sci., February supplement: 30-34.

11. Codina, J., Hildebrandt, J. D., Birnbaumer, L., and Sekura, R. D. (1984) Effects of guanine nucleotides and $\mathrm{Mg}$ on human erythrocyte $\mathrm{N}_{\mathrm{i}}$ and $\mathrm{N}_{\mathrm{s}}$, the regulatory 
components of adenylyl cyclase. J. Biol. Chem., 259: 11408-11418.

12. Dascal, N., Ifune, C., Hopkins, R., Snutch, T. P., Lübbert, H., Davidson, N., SimON, M. I., and LESTER, H. A. (1986) Involvement of a GTP-binding protein in mediation of serotonin and acetylcholine responses in Xenopus oocytes injected with rat brain messenger RNA. Mol. Brain Res., 1: 201-209.

13. Dolphin, A. C. and Scott, R. H. (1987) Calcium channel currents and their inhibition by (-)-baclofen in rat sensory neurones: Modulation by guanine nucleotides. J. Physiol. (Lond.), 386: 1-17.

14. El-Fakahany, E. E., Alger, B. E., Lai, W. S., Pitler, T. A., Worley, P. F., and Baraban, J. M. (1988) Neuronal muscarinic responses: Role of protein kinase C. FASEB J., 2: 2575-2583.

15. Ewald, D. A., Sternweis, P. C., and Miller, R. J. (1988) Guanine nucleotidebinding protein $\mathrm{G}_{0}$-induced coupling of neuropeptide $\mathrm{Y}$ receptors to $\mathrm{Ca}^{2+}$ channels in sensory neurons. Proc. Natl. Acad. Sci. U.S.A., 85: 3633-3637.

16. Flockerzi, V., Oeken, H.-J., Hofmann, F., Pelzer, D., Cavalíe, A., and Trautwein, W. (1986) Purified dihydropyridine-binding site from skeletal muscle t-tubules is a functional calcium channel. Nature, 323: 66-68.

17. Gibbs, J. B., Sigal, I. S., Poe, M., and Scolnick, E. M. (1984) Intrinsic GTPase activity distinguishes normal and oncogenic ras p21 molecules. Proc. Natl. Acad. Sci. U.S.A., 81: 5704-5708.

18. Gierschik, P., Milligan, G., Pines, M., Goldsmith, P., Codina, J., Klee, W., and SPIEGEL, A. (1986) Use of specific antibodies to quantitate the guanine nucleotidebinding protein $\mathrm{G}_{0}$ in brain. Proc. Natl. Acad. Sci. U.S.A., 83: 2258-2262.

19. GiersCHIK, P. and SPIEGEL, A. M. (1985) Chymotrypsin selectively decreases forskolin stimulation of adenylate cyclase. Arch. Biochem. Biophys., 242: 457-463.

20. Gilman, A. G. (1984) G proteins and dual control of adenylate cyclase. Cell, 36: $577-579$.

21. Gilman, A. G. (1987) G proteins: Transducers of receptor-generated signals. Annu. Rev. Biochem., 56: 615-649.

22. Hakozaki, S., Matsumoto, M., and SASaki, K. (1989) Temperature-sensitive activation of $\mathrm{G}$-protein regulating the resting membrane conductance of Aplysia neurons. Jpn. J. Physiol., 39: 115-130.

23. Hescheler, J., Rosenthal, W., Trautwein, W., and Schultz, G. (1987) The GTPbinding protein, $\mathrm{G}_{0}$, regulates neuronal calcium channels. Nature, 325: 445-447.

24. Horne, W. A., Abdel-Ghany, M., Racker, E., Weiland, G. A., Oswald, R. E., and Cerione, R. A. (1988) Functional reconstitution of skeletal muscle $\mathrm{Ca}^{2+}$ channels: Separation of regulatory and channel components. Proc. Natl. Acad. Sci. U.S.A., 85: 3718-3722.

25. Hsia, J. A., Moss, J., Hewlett, E. L., and Vaughan, M. (1984) ADP-ribosylation of adenylate cyclase by pertussis toxin. Effects on inhibitory agonist binding. J. Biol. Chem., 259: 1086-1090.

26. Inoue, M., Nakajima, S., and Nakajima, Y. (1988) Somatostatin induces an inward rectification in rat locus coeruleus neurones through a pertussis toxin-sensitive mechanism. J. Physiol. (Lond.), 407: 177-198.

27. Jelsema, C. L. and Axelrod, J. (1987) Stimulation of phospholipase $\mathrm{A}_{2}$ activity in bovine rod outer segments by the $\beta \gamma$ subunits of transducin and its inhibition by the $\alpha$ subunit. Proc. Natl. Acad. Sci. U.S.A., 84: 3623-3627.

28. Katada, T., Gilman, A. G., Watanabe, Y., Bauer, S., and Jakobs, K. H. 
(1985) Protein kinase $\mathrm{C}$ phosphorylates the inhibitory guanine-nucleotide-binding regulatory component and apparently suppresses its function in hormonal inhibition of adenylate cyclase. Eur. J. Biochem., 151: 431-437.

29. KATADA, T. and Ui, M. (1985) Transmembrane control. Receptor-adenylate cyclase coupling. Seitai no Kagaku, 36: 4-10 (in Japanese).

30. Kim, D., Lewis, D. L., Graziadei, L., Neer, E. J., Bar-Sagi, D., and Clapham, D. E. (1989) G-protein $\beta \gamma$-subunits activate the cardiac muscarinic $\mathrm{K}^{+}$-channel via phospholipase $\mathrm{A}_{2}$. Nature, 337: 557-560.

31. Krapivinsky, G. B., Filatov, G. N., Filatova, E. A., Lyubarsky, A. L., and Fesenko, E. E. (1989) Regulation of cGMP-dependent conductance in cytoplasmic membrane of rod outer segments by transducin. FEBS Lett., 247: 435-437.

32. Kurachi, Y., Ito, H., Sugimoto, T., Shimizu, T., Miki, I., and Ui, M. (1989) Arachidonic acid metabolites as intracellular modulators of the $\mathrm{G}$ proteingated cardiac $\mathrm{K}^{+}$channel. Nature, 337: 555-557.

33. Kurachi, Y., Nakajima, T., and Sugimoto, T. (1986) Role of intracellular $\mathrm{Mg}^{2+}$ in the activation of muscarinic $\mathrm{K}^{+}$channel in cardiac atrial cell membrane. Pflügers Arch., 407: 572-574.

34. Lewis, D. L., Weight, F. F., and LuINI, A. (1986) A guanine nucleotide-binding protein mediates the inhibition of voltage-dependent calcium current by somatostatin in a pituitary cell line. Proc. Natl. Acad. Sci. U.S.A., 83: 9035-9039.

35. LimBiRD, L. E. (1988) Receptors linked to inhibition of adenylate cyclase: Additional signaling mechanisms. FASEB J., 2: 2686-2695.

36. Lo, W. W. Y. and Hughes, J. (1987) Receptor-phosphoinositidase C coupling. Multiple G-proteins? FEBS Lett., 224: 1-3.

37. Logothetis, D. E., Kim, D., Northup, J. K., Neer, E. J., and Clapham, D. E. (1988) Specificity of action of guanine nucleotide-binding regulatory protein subunits on the cardiac muscarinic $\mathrm{K}^{+}$channel. Proc. Natl. Acad. Sci. U.S.A., 85: 5814-5818.

38. Logothetis, D. E., Kurachi, Y., Galper, J., Neer, E. J., and Clapham, D. E. (1987) The $\beta \gamma$ subunits of GTP-binding proteins activate the muscarinic $\mathrm{K}^{+}$channel in heart. Nature, 325: 321-326.

39. Manning, D. R. and Gilman, A. G. (1983) The regulatory components of adenylate cyclase and transducin. A family of structurally homologous guanine nucleotidebinding proteins. J. Biol. Chem., 258: 7059-7063.

40. Matsumoto, M., Sasaki, K., Sato, M., Shozushima, M., and Takashima, K. (1988) Dopamine-induced depolarizing responses associated with negative slope conductance in LB-cluster neurones of Aplysia. J. Physiol. (Lond.), 407: 199-213.

41. Mattera, R., Graziano, M. P., Yatani, A., Zhou, Z., Graf, R., Codina, J., Birnbaumer, L., Gilman, A. G., and Brown, A. M. (1989) Splice variants of the $\alpha$ subunit of the $G$ protein $G_{s}$ activate both adenylyl cyclase and calcium channels. Science, 243: 804-807.

42. Miller, R. J. (1987) Multiple calcium channels and neuronal function. Science, 235: 46-52.

43. NeER, E. J. and Clapham, D. E. (1988) Roles of G protein subunits in transmembrane signalling. Nature, 333: 129-134.

44. NeER, E. J., LoK, J. M., and Wolf, L. G. (1984) Purification and properties of the inhibitory guanine nucleotide regulatory unit of brain adenylate cyclase. J. Biol. Chem., 259: 14222-14229.

45. Osterrieder, W., Brum, G., Hescheler, J., Trautwein, W., Flockerzi, V., and 
HofmanN, F. (1982) Injection of subunits of cyclic AMP-dependent protein kinase into cardiac myocytes modulates $\mathrm{Ca}^{2+}$ current. Nature, 298: 576-578.

46. Paupardin-Tritsch, D., Hammond, C., Gerschenfeld, H. M., Nairn, A. C., and Greengard, P. (1986) cGMP-dependent protein kinase enhances $\mathrm{Ca}^{2+}$ current and potentiates the serotonin-induced $\mathrm{Ca}^{2+}$ current increase in snail neurones. Nature, 323: 812-814.

47. Piomelli, D., Volterra, A., Dale, N., Siegelbaum, S. A., Kandel, E. R., Schwartz, J. H., and Belardetti, F. (1987) Lipoxygenase metabolites of arachidonic acid as second messengers for presynaptic inhibition of Aplysia sensory cells. Nature, 328: 38-43.

48. Rane, S. G. and Dunlap, K. (1986) Kinase C activator 1,2-oleoylacetylglycerol attenuates voltage-dependent calcium current in sensory neurons. Proc. Natl. Acad. Sci. U.S.A., 83: 184-188.

49. Roof, D. J., Applebury, M. L., and Sternweis, P. C. (1985) Relationships within the family of GTP-binding proteins isolated from bovine central nervous system. J. Biol. Chem., 260: 16242-16249.

50. Rosenthal, W., Hescheler, J., Trautwein, W., and Schultz, G. (1988) Control of voltage-dependent $\mathrm{Ca}^{2+}$ channels by $\mathrm{G}$ protein-coupled receptors. FASEB J., 2: 27842790.

51. Rosenthal, W. and Schultz, G. (1987) Modulations of voltage-dependent ion channels by extracellular signals. Trends Pharmacol. Sci., 8: 351-354.

52. Sabol, S. L. and Nirenberg, M. (1979) Regulation of adenylate cyclase of neuroblastoma $\times$ glioma hybrid cells by $\alpha$-adrenergic receptors. 1 . Inhibition of adenylate cyclase mediated by $\alpha$ receptors. J. Biol. Chem., 254: 1913-1920.

53. Sakmann, B., Noma, A., and Trautwein, W. (1983) Acetylcholine activation of single muscarinic $\mathrm{K}^{+}$channels in isolated pacemaker cells of the mammalian heart. Nature, 303: 250-253.

54. SASAKI, K. and SATO, M. (1987) A single GTP-binding protein regulates $\mathrm{K}^{+}$-channels coupled with dopamine, histamine and acetylcholine receptors. Nature, 325: 259-262.

55. Sasaki, K., Takahashi, J., Matsumoto, M., Takashima, K., Hakozaki, S., and Sato, M. (1987) Islet activating protein-sensitive guanosine triphosphate-binding protein regulates $\mathrm{K}^{+}$-channels coupled with FMRFamide receptors. Jpn. J. Physiol., 37: 551557.

56. Scott, R. H. and Dolphin, A. C. (1987) Activation of a $G$ protein promotes agonist responses to calcium channel ligands. Nature, 330: 760-762.

57. Sibley, D. R., Nambi, P., Peters, J. R., and Lefkowitz, R. J. (1984) Phorbol diesters promote $\beta$-adrenergic receptor phosphorylation and adenylate cyclase desensitization in duck erythrocytes. Biochem. Biophys. Res. Commun., 121: 973-979.

58. SPIEGEL, A. M. (1987) Signal transduction by guanine nucleotide binding proteins. Mol. Cell. Endocrinol., 49: 1-16.

59. Sternweis, P. C. and Robishaw, J. D. (1984) Isolation of two proteins with high affinity for guanine nucleotides from membranes of bovine brain. J. Biol. Chem., 259: $13806-13813$.

60. Stryer, L. (1986) Cyclic GMP cascade of vision. Annu. Rev. Neurosci., 9: 87-119.

61. Stryer, L. and Bourne, H. R. (1986) G proteins: A family of signal transducers. Annu. Rev. Cell Biol., 2: 391-419.

62. Sullivan, K. A., Miller, R. T., Masters, S. B., Beiderman, B., Heideman, W., and BOURNE, H. R. (1987) Identification of receptor contact site involved in receptor-G 
protein coupling. Nature, 330: 758-760.

63. UI, M. (1984) Islet-activating protein, pertussis toxin: A probe for functions of the inhibitory guanine nucleotide regulatory component of adenylate cyclase. Trends Pharmacol. Sci., 5: 277-279.

64. Vallar, L. and Meldolesi, J. (1989) Mechanisms of signal transduction at the dopamine $\mathrm{D}_{2}$ receptor. Trends Pharmacol. Sci., 10: 74-77.

65. Van Dop, C., Yamanaka, G., Steinberg, F., Sekura, R. D., Manclark, C. R., STRYeR, L., and BOURNE, H. R. (1984) ADP-ribosylation of transducin by pertussis toxin blocks the light-stimulated hydrolysis of GTP and cGMP in retinal photoreceptors. J. Biol. Chem., 259: 23-26.

66. Vogel, S. S., Chin, G. J., Mumby, S. M., Schonberg, M., and Schwartz, J. H. (1989) G proteins in Aplysia: Biochemical characterization and regional and subcellular distribution. Brain Res., 478: 281-292.

67. Wessling-Resnick, M., Kelleher, D. J., Weiss, E. R., and Johnson, G. L. (1987) Enzymatic model for receptor activation of GTP-binding regulatory proteins. Trends Biochem. Sci., 12: 473-477.

68. Worley, P. F., Baraban, J. M., Van Dop, C., Neer, E. J., and Snyder, S. H. (1986) $\mathrm{G}_{0}$, a guanine nucleotide-binding protein: Immunohistochemical localization in rat brain resembles distribution of second messenger systems. Proc. Natl. Acad. Sci. U.S.A., 83: 4561-4565.

69. Yamashita, N., Shibuya, N., and Ogata, E. (1988) Requirement of GTP on somatostatin-induced $\mathrm{K}^{+}$current in human pituitary tumor cells. Proc. Natl. Acad. Sci. U.S.A., 85: 4924-4928.

70. Yatani, A., Hamm, H., Codina, J., Mazzoni, M. R., Birnbaumer, L., and Brown, A. M. (1988) A monoclonal antibody to the $\alpha$ subunit of $\mathrm{G}_{\mathrm{k}}$ blocks muscarinic activation of atrial $\mathrm{K}^{+}$channels. Science, 241: 828-831.

71. Yatani, A., Imoto, Y., Codina, J., Hamilton, S. L., Brown, A. M., and Birnbaumer, L. (1988) The stimulatory $\mathrm{G}$ protein of adenylyl cyclase, $G_{\mathrm{s}}$, also stimulates dihydropyridine-sensitive $\mathrm{Ca}^{2+}$ channels. J. Biol. Chem., 263: 9887-9895.

72. Yatani, A., Mattera, R., Codina, J., Graf, R., Okabe, K., Padrell, E., Iyengar, R., Brown, A. M., and Birnbaumer, L. (1988) The G protein-gated atrial $\mathrm{K}^{+}$channel is stimulated by three distinct $\mathrm{G}_{i} \alpha$-subunits. Nature, 336: 680-682. 